\title{
MORALIDADE E EDUCAÇÃO NA MODERNIDADE LÍQUIDA ${ }^{1}$
}

\author{
Roberto Rafael Dias da Silva ${ }^{2}$
}

Embora uma atitude consumista possa lubrificar as rodas da economia, ela joga poeira nos vagões de moralidade (BAUMAN, 2014, p. 181).

As contribuições do pensamento de Zygmunt Bauman para a compreensão da sociedade contemporânea têm sido abrangentes e significativas. Seu aparato conceitual - em especial suas conceituações vinculadas à emergência de uma "modernidade líquida" frequentemente subsidia pesquisas no âmbito de uma sociologia da educação de caráter compreensivo e humanista. Uma de suas últimas obras traduzidas no Brasil, a qual apreciaremos criticamente nesta resenha, intitula-se "Cegueira moral: a perda da sensibilidade na modernidade líquida". Trata-se de um diálogo estabelecido com o filósofo lituano Leonidas Donskis, no qual são examinados aspectos referentes à vida humana no estágio atual da Modernidade, sobremaneira a ênfase de estarmos perdendo a sensibilidade em relação aos outros, uma espécie de anestesia diante do sofrimento alheio, enfim uma "cegueira moral".

Para estabelecer uma reflexão sobre a moralidade na Contemporaneidade, os autores partem da questão filosófica acerca da origem do mal. Ao reconhecer que o mal não se reduz às guerras ou ideologias totalitárias, nem mesmo ao diabo e às figuras da escatologia medieval, argumentam que, hoje, o mal é "fraco e invisível" (p. 17). Ao explicar essa afirmativa, Donskis sugere que, na modernidade líquida, "felizes eram os tempos em que havia formas evidentes de mal. Hoje não sabemos mais quais são elas e onde estão. Tudo se torna claro quando alguém perde a memória e a capacidade de ver e sentir" (p. 18). Essa seria a nomeada "cegueira moral", resignadamente aceita e justificada pelos imperativos do

\footnotetext{
1 BAUMAN, Zygmunt; DONSKIS, Leonidas. Cegueira moral: a perda da sensibilidade na modernidade líquida. Rio de Janeiro: Zahar, 2014.

2 Doutorado e Mestrado em Educação. Endereço: Universidade do Vale do Rio dos Sinos, Programa de PósGraduação em Educação., Avenida Unisinos, Cristo Rei, 93022000 - São Leopoldo, RS - Brasil. Endereço eletrônico: robertoddsilva@yahoo.com.br
} 
mercado, do Estado, das estatísticas e avaliações diversas. Em linhas gerais, o livro apresenta-se como "um diálogo sobre uma possibilidade de redescoberta do sentido de pertencimento como alternativa viável à fragmentação, atomização e à resultante perda de sensibilidade" (p. 19).

Um dos conceitos utilizados por Bauman para tratar dessa questão é a "adiaforização", isto é, o afastamento das preocupações sobre a avaliação moral. O indivíduo, em suas novas redes, torna-se insensível ou indiferente às dificuldades dos outros. Em sua versão líquida, ainda conforme o pensador social, a adiaforização aproxima-se da relação entre consumidor e mercadoria, tornando dispensáveis as peças que não estão na moda, em um tempo cada vez mais curto. O desafio apresentado no diálogo entre os autores, sistematizado em cinco capítulos, dirige-se a problematizar as condições sociais de nosso tempo e, concomitantemente, contribuir para "recuperar nossa sagacidade em tempos sombrios" (p.18). Apresentaremos e comentaremos cada um dos capítulos, a partir deste momento.

O primeiro capítulo, intitulado "Do diabo a pessoas assustadoramente normais e sensatas", ao continuar o diálogo iniciado na introdução, sobre as origens do mal - unde malum, dirige-se para a questão do individualismo e da indiferença, apresentadas como formas contemporâneas de sociabilidade. De acordo com Bauman, não encontramos mais figuras diabólicas como o Mefisto de Goethe, mas uma configuração de pensamento alicerçada na ideia de "faça você mesmo". Diferenciando-se da figura de Goethe, então, o pensador afirma que o mal tornou-se "difuso e disperso, desregulado e impessoal por ter sido depositado, pulverizado e espargido sobre o enxame humano, gerando miríades de 'agentes locais' depois privatizados e 'terceirizados' para nós, homens e mulheres, como indivíduos" (p. 35). A nova liturgia do mal estaria alicerçada na produção de identidades privatizadas, que se afastam das demandas da coletividade.

Outra nuance dessa questão, esboçada no diálogo entre Bauman e Donskis, localiza-se na indiferença. De acordo com o filósofo lituano, a preocupação estaria no "perigo de perder nossa capacidade de acompanhar o que está acontecendo no mundo e de nos solidarizarmos com as pessoas que sofrem" (p. 53). Por outro lado, explorando a problemática da indiferença moral, Bauman traz uma de suas noções já utilizadas em obras anteriores - a emergência do "homo eligens".

O que separa a atual agonia da escolha dos desconfortos que sempre atormentaram o homo eligens, o "homem que escolhe", é a descoberta ou a suspeita de que não existem regras preordenadas e objetivos universalmente aprovados que possam ser 
seguidos para absolver aqueles que escolhem das consequências adversas de suas escolhas (p. 54).

A compreensão desse cenário de indiferença moral é direcionada para o campo da política no segundo capítulo, nomeado como "A crise da política e a busca da linguagem da sensibilidade". O primeiro aspecto explorado refere-se aos modos pelos quais a tecnologia ultrapassou a política, especialmente através das conhecidas "redes sociais". Conforme Bauman, acerca das relações entre público e privado, "vivemos numa sociedade confessional, promovendo a autoexposição pública ao posto de principal e mais disponível das provas de existência social, assim como a mais possante e a única eficiente" (p. 71). Associado a isso, o segundo aspecto é a perda de fé na política, evidenciado no constante fenômeno de saída do povo às ruas.

$\mathrm{Na}$ medida em que as formas de representação política entram em declínio, parecem emergir formas individualizantes de intervenção, geralmente indicadas na formulação "conte com seus próprios recursos" (p. 87). Característica desse cenário é a proliferação e autopropulsão aos medos, cada vez mais "desregulamentados e privatizados" (p. 98), sobretudo propulsionados de uma crise de agência do Estado.

O terceiro capítulo, "Entre o medo e a indiferença: a perda da sensibilidade", trata das condições sociais contemporâneas caracterizadas pela "incerteza prolongada". Considerando que o medo e a modernidade são "irmãos gêmeos", Bauman argumenta que, atualmente, nossos medos dirigem-se ao bem-estar, em uma espécie de "guerra ao desconforto" (p. 119). A relação entre medo e indiferença, então, situa-se em um jogo permanente de vulnerabilidades e de fragilidades, sobre as quais a depressão emerge como a principal doença de nosso tempo. Na medida em que o Estado previdenciário tem diminuído suas formas de ação, os indivíduos permanecem expostos às inseguranças do mercado, às fragilidades subjetivas e aos direcionamentos midiáticos.

O capítulo quarto versa sobre a universidade contemporânea e sua possível perda de critérios, sobretudo em um tempo de capitalização do conhecimento e de restrições à liberdade acadêmica. A educação, conforme a reflexão proposta por Bauman, apresenta-se como "a preparação de recém-chegados à sociedade para a vida social na qual estão se qualificando a fim de nela ingressar" (p. 171). Entretanto, a educação atualmente enfrenta profunda crise, na medida em que preparamos os jovens para um mundo que "torna nula e vazia a própria ideia de 'ser preparado'" (p. 171). Tal condição agudiza-se nas configurações 
de uma "cultura agorista", impaciente para reconhecer que a formação humana se dá em longo prazo.

Na sociedade de produtores que agora já fica no passado (pelo menos em nossa parte do planeta), o conselho num caso como esse seria "esforçar-se ainda mais". Mas isso não acontece na sociedade de consumidores. Aqui, as ferramentas que falharam devem ser atiradas na lata de lixo, e não afiadas e de novo utilizadas com mais habilidade e dedicação, com melhor efeito (p. 173-174).

Por fim, no quinto e último capítulo, Zygmunt Bauman e Leonidas Donskis comentam duas obras literárias - "A decadência do Ocidente" de Spengler e "A possibilidade de uma ilha" de Howellebecq - visando analisar o estágio atual da Europa e suas mudanças culturais. O principal aspecto destacado diz respeito à soberania dos Estados Nacionais, sob as condições da interdependência global. Na medida em que poder e política estão cada vez mais dissociados, Bauman reitera que "nossos instrumentos de ação coletiva e de expressão de nossa vontade ainda são locais e resistentes à ampliação, violação e/ou limitação" (p. 224). Este seria o "metadesafio" da cultura e da política mobilizados no Ocidente.

De maneira a finalizar essa resenha, importa assinalar a potencialidade analítica deste diálogo entre Bauman e Donskis, sobretudo para os pesquisadores educacionais dispostos a mobilizar uma sociologia compreensiva e humanista. Pensar sobre as configurações líquidas de nossa modernidade pode nos conduzir a uma inescapável reflexão na atualidade, a saber: a insensibilidade com as desigualdades e a cegueira moral. O livro apresentado neste breve texto, longe de apresentar respostas definitivas, incita-nos a produzir novas e inquietantes indagações acerca dos processos de formação humana.

Data de recebimento: 04/05/2015

Data de aceite: 15/02/2016 